\title{
Penerapan Media Pembelajaran Peta Tiga Dimensi Melalui Pembelajaran Tutor Sebaya Untuk Meningkatkan Hasil Belajar IPS Pada Siswa Kelas IV SDN Banjaran Kecamatan Driyorejo Kabupaten Gresik
}

\author{
Ery Rahmawati ${ }^{1}$, Galuh Kartika Dewi ${ }^{2}$ \\ ${ }^{12}$ PGSD, STKIP PGRI SIDOARJO \\ Email: eryrahmawati521@gmail.com, galuhkartika86@gmail.com
}

\begin{abstract}
This study aims to identify and describe the social studies learning outcomes and student activeness after applying the three-dimensional map learning media through peer tutoring learning for fourth grade students of SDN Banjaran, Driyorejo District, Gresik Regency. This research on learning improvement is supported by the ability of grade IV students at SDN Banjaran Driyorejo-Gresik who do not meet the predetermined learning completeness criteria. From this problem, learning improvement is carried out in two cycles using the Classroom Action Research method by applying three-dimensional map learning media through peer tutoring learning. There are four stages in each cycle, namely planning, implementing, observing, and reflecting activities. The results showed that there was an increase in the average student learning outcomes from precycle 62.12 to cycle I of 75.19, and the result of cycle II to reach 84.14. Classical completeness of student learning outcomes also increased from $23.81 \%$ pre-cycle to $62.12 \%$ first cycle to second cycle of $92.31 \%$. Student learning activities also increased from pre-cycle by $51 \%$ then cycle I $72 \%$ and cycle II reached $87 \%$. Thus, it can be concluded that the application of three-dimensional map learning media through peer tutoring can improve social studies learning outcomes in fourth grade students of SDN Banjaran, Driyorejo-Gresik.
\end{abstract}

Keywords: three dimensional map, peer tutor learning, learning outcomes

Abstrak. Penelitian ini bertujuan untuk mengetahui dan mendeskripsikan hasil belajar IPS dan keaktifan siswa setelah menerapkan media pembelajaran peta tiga dimensi melalui pembelajaran tutor sebaya pada siswa kelas IV SDN Banjaran Kecamatan Driyorejo kabupaten Gresik. Penelitian perbaikan pembelajaran ini dilatar belakangi oleh kemampuan siswa kelas Kelas IV SDN Banjaran Driyorejo-Gresik yang belum memenuhi kriteria ketuntasan belajar yang sudah ditentukan. Dari masalah tersebut dilakukan perbaikan pembelajaran dengan dua siklus dalam menggunakan metode Penelitian Tindakan Kelas dengan menerapkan media pembelajaran peta tiga dimensi melalui pembelajaran tutor sebaya. Ada empat tahap dalam setiap siklus yaitu perencanaan, pelaksanaan, observasi, dan kegiatan refleksi. Hasil penelitian menunjukkan bahwa ada peningkatan rata-rata hasil belajar siswa dari pra siklus 62,12 ke siklus I sebesar 75,19, dan hasi siklus II mencapai 84,14. Ketuntasan hasil belajar siswa secara klasikal juga mengalami peningkatan dari pra siklus $23,81 \%$ ke siklus I $62,12 \%$ ke siklus II sebesar $92,31 \%$. Aktivitas belajar siswa juga mengalami peningkatan dari pra siklus sebesar 51\% kemudian siklus I 72\% dan siklus II mencapai $87 \%$. Dengan demikian dapat disimpulkan bahwa penerapan media pembelajaran peta tiga dimensi melalui pembelajaran tutor sebaya dapat meningkatkan hasil belajar IPS pada siswa kelas IV SDN Banjaran kecamatan Driyorejo Kabupaten Gresik.

Kata Kunci: peta tiga dimensi, pembelajaran tutor sebaya, hasil belajar

\section{PENDAHULUAN}

Ilmu Pengetahuan Sosial (IPS) merupakan salah satu mata pelajaran yang diberikan di sekolah dasar yang menkaji seperangkat peristiwa, fakta, konsep yang berkaitan dengan sosial. Menurut Daldjoeni (2014) materi IPS bersumber pada pusat kegiatan hidup manusia seperti manusia dengan alam lingkungannya, manusia dengan kelompoknya, manusia dengan manusia 
lainnya dalam usaha mencari nafkah, usaha mengadakan impuls agama dan seterusnya Proses pembelajaran ini akan berjalan sesuai dengan tujuan jika ada fasilitas yang memadai.

Materi Ilmu Pengetahuan Sosial sering disebut peserta didik sebagai sebuah materi penghafal saja tanpa mengambil makna yang terkandung dalam materi tersebut. Anggapan tersebut dapat muncul karena kebosanan siswa dalam menerima pelajaran hanya melalui penjelasan dari guru yang monoton dan tidak variatif, sehingga kondisi kelas pun menjadi tidak kondusif. .

Hal serupa telah penulis temukan dalam pembelajaran IPS di kelas IV SDN Banjaran, Driyorejo Gresik. Dimana siswa hanya mendengarkan penjelasan guru tanpa mampu memahami dan menguasai konsepkonsep yang sebenarnya sangat penting bagi kehidupan mereka kelak. Salah satu upaya yang harus dilakukan guru agar siswa mampu memahami dan menguasai konsep-konsep dengan lebih optimal, guru harus bersikap lebih teliti dalam memilih metode dan media pembelajaran.Pemahaman siswa SDN Banjaran mengenai materi peta dalam subtema Indahnya Keragaman Budaya Negeriku sangat kuranghanya beberapa siswa yang memahami materi tersebut. Terdapat 5 dari 26 siswa yang mendapatkan nilai di atas 70. Sedangkan sisanya mendapatkan nilai dibawah 70 . Padahal standar ketuntasan nilai (KKM) yang tentukan adalah 70 .

Dari fenomena diatas, masalah yang harus segera dicari solusinya tentang rendahnya hasil belajar siswa dalam memahami "materi peta" dalam subtema Indahnya Keragaman Negeriku. Hal ini disebabkan guru kurang dapat menyesuaikan metode dan media pembelajaran dengan karakteristik dan kebutuhan belajar atau guru kurang tepat dalam memilih metode dan media pembelajaransiswa kelas IV SDN Banjaran Driyorejo Gresik .

Melihat dari realita tersebut maka peneliti mencari pemecahan masalah. Salah satu alternatif yang peneliti pilih dengan menerapkan media pembelajaran peta tiga dimensi melalui pembelajaran tutor sebaya. Menurut Ibrahim (2006) dalam jurnal Masrianto Agus,dkk secara fisik peta timbul termasuk model lapangan walaupun objek lokasi yang lebih luas memiliki ukuran panjang dan lebar, peta timbul jika dibandingkan dengan peta datar lebih mudah memberikan pengertian atau gambaran tentang keadaan permukaan bumi. Menurut Arsyad dalam jurnal Masrianto Agus,dkk (2017) media berfungsi untuk tujuan intruksi dimana informasi yang terdapat dalam media itu harus melibatkan siswa baik dalam benak ataupun mental maupun dalam bentuk aktivitas yang nyata sehingga pembelajaran dapat terjadi.

Adapun penelitian terdahulu yaitu penelitian oleh Setyawan, A. D. C, dkk. (2017) dengan judul Pengembangan Media Tiga Dimensi dalam Pembelajaran Model Student Team Achievement Division untuk Meningkatkan Hasil Belajar Siswa pada Subtema Lingkungan Tempat Tinggalku Kelas IV Sekolah Dasar. Penelitian ini bertujuan untuk mengembangkan media tiga dimensi berupa model kenampakan alam dan media peta timbul yang valid, praktis, dan efektif. Hasil penenlitian menunjukkan media yang dikembangkan valid, praktis, dan efektif untuk meningkatkan hasil belajar.

Penelitian dari Ningsih, W. K, dkk (2019) dengan judul The Development of Pop Up 3D General Map Using Discovery Learning Models to Improve Creativity and Learning Outcomes of Social Studies Grade V Elementary School. Hasil penelitian menunjukkan hasil belajar ranah kognitif mencapai $94,12 \%$, hasil belajar ranah afektif $82 \%$ mencapai kriteria baik, dan ranah psikomotor menunjukkan 88,24\% termasuk kriteria baik. Dengan demikian peta pop Up 3D dapat digunakan sebagai alternatif pembelajaran IPS di Kelas V Sekolah Dasar.

Metode pembelajaran Tutor Sebaya menurut Depdiknas dalam Majid (2013:206) merupakan kegiatan pembelajaran yang dilakukan seorang siswa kepada siswa lainnya dan salah satu siswa itu lebih memahami materi.Kualitas hasil belajar siswa tidak bisa lepas dari seberapa baik dan berkualitasnya seorang pendidik (guru) dalam melaksanakan kegiatan pembelajaran. Namun demikian guru bukanlah satu-satunya sumber belajar, beberapa siswa yang memiliki kecepatan belajar yang lebih baik dapat dimanfaatkan 
guru untuk membantu teman-temannya yang memiliki kecepatan belajar sedikit lambat, supaya kegiatan pembelajaran bisa lebih efektif serta optimal. Penerapan kegiatan pembelajaran seperti ini sangat mengedepankan pendekatan keterampilan proses, dimana guru bersama siswa terlibat aktif secara langsung dalam setiap tahap pembelajaran.

Media pembelajaran yang sesuai dalam pembelajaran IPS materi peta dalam subtema Indahnya Keragaman Budaya Negeriku yaitu media pembelajaran peta tiga dimensi. Peta tiga dimensi adalah peta yang digambarkan dan di buat dari bahan bubur kertas sehingga hasilnya tampak seperti keadaan yang sebenarnya. Penggunaan media pembelajaran peta tiga dimensi diharapkan dapat meningkatkan hasil belajar pada mata pelajaran IPS khususnya dalam pembelajaran tentang peta dalam subtema Indahnya Keragaman Budaya Negeriku.

Berdasar pada pemikiran di atas, maka penulis melakukan penelitian tindakan kelas dengan judul Penerapan Media Pembelajaran Peta Tiga Dimensi Melalui Pembelajaran Tutor Sebaya untuk Meningkatkan Hasil Belajar IPS pada Siswa Kelas IVSDN Banjaran Kecamatan Driyorejo Kabupaten Gresik. Tujuan dari penelitian ini adalah untuk mengetahui dan mendeskripsikan hasil belajar dan keaktifan siswa setelah menerapkan media pembelajaran peta tiga dimensi melalui pembelajaran tutor sebaya.

\section{METODE PENELITIAN}

Penelitian ini menggunakan desain Classroom Action Research atau Penelitian Tindakan Kelas (PTK).Menurut Mukhlis (2000: 5) PTK adalah suatu bentuk kajian yang bersifat sistematis reflektif oleh pelaku tindakan untuk memperbaiki kondisi pembelajaran yang dilakukan.Adapun tujuan utama dari PTK adalah untuk memperbaiki/ meningkatkan pratek pembelajaran secara berkesinambungan, sedangkan tujuan penyertaannya adalah menumbuhkan budaya meneliti di kalangan guru (Mukhlis, 2000 : 5).

Berdasarkan tujuan penelitian, maka metode penelitian yang digunakan adalah Penelitian Tindakan Kelas (PTK). Model proses yang digunakan dalam PTK ini adalah Model Proses Siklus (Putaran/Spiral) yang mengacu pada model PTK Kemmis S, dan Mc. Taggart R. Adapun rancangan siklus penelitian memiliki empat tahapan kegiatan pada setiap siklusnya, yaitu (1) membuat rencana tindakan, (2) melaksanakan tindakan, (3) mengadakan pengamatan/ observasi, (4) memberikan refleksi dan evaluasi untuk memperoleh sejauh mana pencapaian hasil yang diharapkan kemudian direvisi untuk melaksanakan tindakan pada siklus berikutnya (Arikunto Suharsimi, 2010: 18).

Dalam menganalisis data hasil ketuntasan belajar siswa secara individu dan ketuntasan secara klasikal digunakan rumus sebagai berikut:

$$
\mathrm{P}=\frac{n}{N} \times 100 \%
$$

\section{Keterangan:}

$$
\begin{array}{ll}
\mathrm{P} & =\text { Presentase ketuntasan klasikal } \\
\mathrm{n} & =\text { Jumlah siswa yang tuntas } \\
\mathrm{N} & =\text { jumlah seluruh siswa }
\end{array}
$$

Untuk menilai soal essay yang telah dilakukan oleh siswa, guru melakukan penjumlahan nilai yang telah diperoleh siswa dibagi dengan jumlah siswa yang ada pada kelas tersebut sehingga diperoleh rata-rata tes formatif sebagai berikut :

$$
\text { Nilai rata-rata }=\frac{\sum X}{\sum n}
$$

Keterangan : $\sum X=$ jumlah semua nilai siswa

$$
\sum \mathrm{N}=\text { jumlah siswa }
$$

Untuk menganalisis data hasil observasi keaktivan siswa selama proses pembelajaran berlangsung peneliti menggunakan rumus sebagai berikut:

$$
\mathrm{P}=\frac{F}{N} \times 100 \%
$$

Keterangan:

$\mathrm{P} \quad=$ Presentase aktivitas siswa

$\mathrm{F} \quad=$ Banyaknya aktivitas siswa yang muncul

$\mathrm{N}=$ Jumlah aktivitas siswa keseluruhan (Indiarti, 2008). 


\section{HASIL DAN PEMBAHASAN}

Hasil dan pembahasan dalam penelitian ini meliputi hasil belajar, aktivitas guru, dan aktivitas siswa. Pelaksanaan pembelajaran pada penelitian tindakan kelas diperoleh data dengan kegiatan pra siklus, siklus 1 , dan siklus 2. Data yang diperoleh adalah data hasil tes dan data penilaian keaktifan siswa dan guru selama proses kegiatan pembelajaran berlangsung. Untuk pra siklus diperoleh data hasil tes sebagai berikut:

Tabel 1 Rekapitulasi Hasil Tes Pra-Siklus

\begin{tabular}{llccc}
\hline No & $\begin{array}{c}\text { Nama } \\
\text { Siswa }\end{array}$ & Nilai & Tuntas & $\begin{array}{c}\text { Tidak } \\
\text { Tuntas }\end{array}$ \\
\hline 1 & AR & 60 & & $\sqrt{ }$ \\
2 & AA & 50 & & $\sqrt{ }$ \\
3 & AAH & 60 & & $\sqrt{ }$ \\
4 & ARA & 65 & & $\sqrt{ }$ \\
5 & BP & 60 & & $\sqrt{ }$ \\
6 & DAF & 65 & & $\sqrt{ }$ \\
7 & FKP & 60 & & $\sqrt{ }$ \\
8 & KPH & 70 & $\sqrt{ }$ & \\
9 & LJP & 60 & & $\sqrt{ }$ \\
10 & MPA & 70 & $\sqrt{ }$ & \\
11 & MP & 65 & & $\sqrt{ }$ \\
12 & MM & 55 & & $\sqrt{ }$ \\
13 & MRSR & 60 & & $\sqrt{ }$ \\
14 & MAM & 65 & & $\sqrt{ }$ \\
15 & MDM & 70 & $\sqrt{ }$ & $\sqrt{ }$ \\
16 & MMAF & 80 & $\sqrt{ }$ & $\sqrt{ }$ \\
17 & MRS & 65 & & $\sqrt{ }$ \\
18 & MRSA & 45 & & $\sqrt{ }$ \\
19 & MYH & 60 & & $\sqrt{ }$ \\
20 & NIM & 55 & & $\sqrt{ }$ \\
21 & NL & 60 & & \\
22 & PAK & 65 & & \\
23 & SAS & 60 & & \\
24 & SMT & 65 & & $\sqrt{ }$ \\
25 & TACL & 70 & & \\
26 & ZLS & 60 & & \\
\hline & Jumlah & 1620 & 5 & \\
\hline
\end{tabular}

Presentase Ketuntasan siswa secara klasikal pada Pra Siklus:

$\mathrm{P}=\frac{n}{\mathrm{~N}^{\prime}} \times 100 \%$

$\mathrm{P}=\frac{5}{26} \times 100 \%$
$\mathrm{P}=23,81 \%$

Berdasarkan hasil perhitungan Pra siklus maka diperoleh data hasil belajar siswa secara klasikal yakni 5 dari 26 siswa dinyatakan Tuntas dan 21 siswa Tidak Tuntas. Siswa memang belum menunjukkan perilaku yang diharapkan. Bila dinyatakan dalam presentase Ketuntasan belajar siswa hanya mencapai 23,81\%. Hasil ini menunjukkan belum tercapainya indikator ketuntasan belajar yang sudah ditentukan yakni $75 \%$. Sehingga diperlukan rencana perbaikan pembelajaran pada siklus I dan diharapkan hasil belajar siswa dapat mencapai indikator keberhasilan yang sudah ditentukan. Hasil kegiatan pembelajaran pra siklus yang diberikan pada siswa dengan pembelajaran konvensional tanpa media pembelajaran memiliki nilai ratarata 62,12 dengan nilai minimum 45 dan nilai maksimum 80.

Berikut data hasil belajar siswa pada siklus I pembelajaran IPS dengan tema Indahnya Keragaman Negeriku, Subtema Indahnya Keragaman Budaya Negeriku menggunakan media peta tiga dimensi :

Tabel 2 Rekapitulasi Hasil Tes Siklus 1

\begin{tabular}{llccc}
\hline No & $\begin{array}{l}\text { Nama } \\
\text { Siswa }\end{array}$ & Nilai & Tuntas & $\begin{array}{c}\text { Tidak } \\
\text { Tuntas }\end{array}$ \\
\hline 1 & AR & 75 & $\sqrt{ }$ & \\
2 & AA & 60 & & $\sqrt{ }$ \\
3 & AAH & 75 & $\sqrt{ }$ & \\
4 & ARA & 80 & $\sqrt{ }$ & \\
5 & BP & 65 & & $\sqrt{ }$ \\
6 & DAF & 80 & $\sqrt{ }$ & \\
7 & FKP & 80 & $\sqrt{ }$ & \\
8 & KPH & 85 & $\sqrt{ }$ & \\
9 & LJP & 65 & & $\sqrt{ }$ \\
10 & MPA & 80 & $\sqrt{ }$ & \\
11 & MP & 75 & $\sqrt{ }$ & \\
12 & MM & 65 & & $\sqrt{ }$ \\
13 & MRSR & 75 & $\sqrt{ }$ & \\
14 & MAM & 80 & $\sqrt{ }$ & \\
15 & MDM & 85 & $\sqrt{ }$ & \\
16 & MMAF & 90 & $\sqrt{ }$ & \\
17 & MRS & 80 & $\sqrt{ }$ & \\
18 & MRSA & 60 & & $\sqrt{ }$ \\
19 & MYH & 75 & $\sqrt{ }$ & \\
20 & NIM & 65 & & $\sqrt{ }$ \\
21 & NL & 80 & $\sqrt{ }$ & \\
22 & PAK & 80 & $\sqrt{ }$ & $\sqrt{ }$ \\
23 & SAS & 65 & & $\sqrt{ }$ \\
\hline
\end{tabular}




\begin{tabular}{llccc}
\hline 24 & SMT & 80 & $\sqrt{ }$ & \\
25 & TACL & 80 & $\sqrt{ }$ & \\
26 & ZLS & 75 & $\sqrt{ }$ & \\
\hline & Jumlah & 1955 & 19 & 7 \\
\hline
\end{tabular}

Presentase Ketuntasan siswa secara klasikal pada Pra Siklus:

$\mathrm{P}=\frac{n}{\mathrm{~N}^{\prime}} \times 100 \%$

$\mathrm{P}=\frac{19}{26} \times 100 \%$

$\mathrm{P}=73,08 \%$

Berdasarkan hasil perhitungan Siklus I pada Tabel 2 dijelaskan bahwa dengan menerapkan media peta tiga dimensi diperoleh data hasil belajar siswa secara klasikal yakni 22 dari 26 siswa dinyatakan Tuntas dan 4 siswa Tidak Tuntas. Bila dinyatakan dalam presentase Ketuntasan belajar siswa kini mencapai 73,08 \%. Hasil ini menunjukkan ketuntasan hasil belajar siswa belum mecapai indikator ketuntasan belajar yang sudah ditentukan sebelumnya yakni 75. Hasil siklus 1 siswa yang diberikan pada pembelajaran menggunakan media peta tiga dimensi memiliki nilai rata-rata 75,19 dengan nilai minimum 60 dan nilai maksimum 90 .

Berikut data hasil belajar siswa pada siklus II pembelajaran IPS dengan tema Indahnya Keragaman Negeriku, Subtema Indahnya Keragaman Budaya Negeriku menggunakan media peta tiga dimensi melalui pembelajaran tutor sebaya:

Tabel 3 Rekapitulasi Hasil Tes Siklus 2

\begin{tabular}{lllcc}
\hline No & $\begin{array}{c}\text { Nama } \\
\text { Siswa }\end{array}$ & Nilai & Tuntas & $\begin{array}{c}\text { Tidak } \\
\text { Tuntas }\end{array}$ \\
\hline 1 & AR & 80 & $\sqrt{ }$ & $\sqrt{ }$ \\
2 & AA & 65 & & \\
3 & AAH & 85 & $\sqrt{ }$ & \\
4 & ARA & 90 & $\sqrt{ }$ & \\
5 & BP & 85 & $\sqrt{ }$ & \\
6 & DAF & 90 & $\sqrt{ }$ & \\
7 & FKP & 85 & $\sqrt{ }$ & \\
8 & KPH & 90 & $\sqrt{ }$ & \\
9 & LJP & 80 & $\sqrt{ }$ & \\
10 & MPA & 90 & $\sqrt{ }$ & \\
11 & MP & 85 & $\sqrt{ }$ & \\
12 & MM & 75 & $\sqrt{ }$ & \\
13 & MRSR & 90 & $\sqrt{ }$ & \\
14 & MAM & 85 & $\sqrt{ }$ & \\
\hline
\end{tabular}

\begin{tabular}{llrcc}
\hline 15 & MDM & 90 & $\sqrt{ }$ & \\
16 & MMAF & 95 & $\sqrt{ }$ & \\
17 & MRS & 85 & $\sqrt{ }$ & \\
18 & MRSA & 65 & & $\sqrt{ }$ \\
19 & MYH & 85 & $\sqrt{ }$ & \\
20 & NIM & 70 & $\sqrt{ }$ & \\
21 & NL & 85 & $\sqrt{ }$ & \\
22 & PAK & 90 & $\sqrt{ }$ & \\
23 & SAS & 85 & $\sqrt{ }$ & \\
24 & SMT & 85 & $\sqrt{ }$ & \\
25 & TACL & 90 & $\sqrt{ }$ & \\
26 & ZLS & 85 & $\sqrt{ }$ & \\
\hline & Jumlah & 2185 & 24 & 2 \\
\hline
\end{tabular}

Presentase Ketuntasan siswa secara klasikal pada Pra Siklus:

$\mathrm{P}=\frac{n}{\mathrm{~N}^{\prime}} \times 100 \%$

$\mathrm{P}=\frac{24}{26} \times 100 \%$

$\mathrm{P}=92,31 \%$

Berdasarkan hasil perhitungan Siklus II maka diperoleh data hasil belajar siswa secara klasikal yakni 24 dari 26 siswa dinyatakan Tuntas dan 2 siswa Tidak Tuntas. Bila dinyatakan dalam presentase Ketuntasan belajar siswa sekarang mencapai 92,31\%, hasil ini mengalami peningkatan sebanyak 19\% dari siklus I, sehingga ketuntasan hasil belajar siswa pada siklus II sudah mencapai indikator keberhasilan yang telah ditetapkan yaitu $\geq 75 \%$. Hasil siklus 2 diperoleh data bahwa nilai rata-rata 84,04 dengan nilai minimum 65 dan nilai maksimum 95. Adanya peningkatan hasil belajar siswa dikarenakan siswa lebih mudah memahami materi dengan menggunakan media peta tiga dimensi meskipun media disaksikan siswa dalam tayangan video serta pembelajaran dengan tutor sebaya. Dengan penggunaan metode pembelajaran tutor sebaya ini mampu membuka peluang siswa untuk bertanya dengan sesama temanya, dan ternyata dari proses bertanya antar siswa ini, siswa lebih mudah menerima penjelasan dari temannya yang lebih paham tentang materi pelejaran tersebut.

Setelah Siklus II selesai dilaksanakan, guru dan peneliti mengadakan refleksi akhir. Dari pengamatan peneliti, secara umum pembelajaran pada siklus II lebih baik 
daripada siklus I. Dengan demikian dapat disimpulkan bahwa Penerapan Media Tiga Dimensi Melalui Pembelajaran Tutor Sebaya telah berhasil dan dapat meningkatkan hasil belajar siswa sehingga tidak perlu dilaksanakan Siklus III.

Berikut disajikan Rekapitulasi Hasil Belajar Siswa pada Pra Siklus, Siklus I dan Siklus II pada Tabel 4.

Tabel 4. Rekapitulasi Hasil Belajar Siswa

Pra Siklus-Siklus I-Siklus II

\begin{tabular}{clccc}
\hline & \multirow{2}{*}{ Nama } & \multicolumn{3}{c}{ Hasil Belajar } \\
& Siswa & Pra & Siklus & Siklus \\
\hline 1 & AR & 60 & 75 & 80 \\
2 & AA & 50 & 60 & 65 \\
3 & AAH & 60 & 75 & 85 \\
4 & ARA & 65 & 80 & 90 \\
5 & BP & 60 & 65 & 85 \\
6 & DAF & 65 & 80 & 90 \\
7 & FKP & 60 & 80 & 85 \\
8 & KPH & 70 & 85 & 90 \\
9 & LJP & 60 & 65 & 80 \\
10 & MPA & 70 & 80 & 90 \\
11 & MP & 65 & 75 & 85 \\
12 & MM & 55 & 65 & 75 \\
13 & MRSR & 60 & 75 & 90 \\
14 & MAM & 65 & 80 & 85 \\
15 & MDM & 70 & 85 & 90 \\
16 & MMAF & 80 & 90 & 95 \\
17 & MRS & 65 & 80 & 85 \\
18 & MRSA & 45 & 60 & 65 \\
19 & MYH & 60 & 75 & 85 \\
20 & NIM & 55 & 65 & 70 \\
21 & NL & 60 & 80 & 85 \\
22 & PAK & 65 & 80 & 90 \\
23 & SAS & 60 & 65 & 85 \\
24 & SMT & 65 & 80 & 85 \\
25 & TACL & 70 & 80 & 90 \\
26 & ZLS & 60 & 75 & 85 \\
\hline & Jumlah & 1620 & 1955 & 2185 \\
\hline Nilai Rata- & 62,12 & 75,19 & 84,04 \\
\hline & & & & \\
MA & & II & \\
\hline
\end{tabular}

\begin{tabular}{lcccc}
\hline \multirow{2}{*}{ No } & \multirow{2}{*}{ Nama } & \multicolumn{3}{c}{ Hasil Belajar } \\
& Siswa & Pra & Siklus & Siklus \\
& Siklus & I & II \\
\hline \multicolumn{2}{l}{ Rata } & & &
\end{tabular}

Berikut ini disajikan diagram data nilai rata-rata Hasil Belajar siswa dari hasil penelitian yang diperoleh pada Pra siklus, siklus I, dan siklus II:

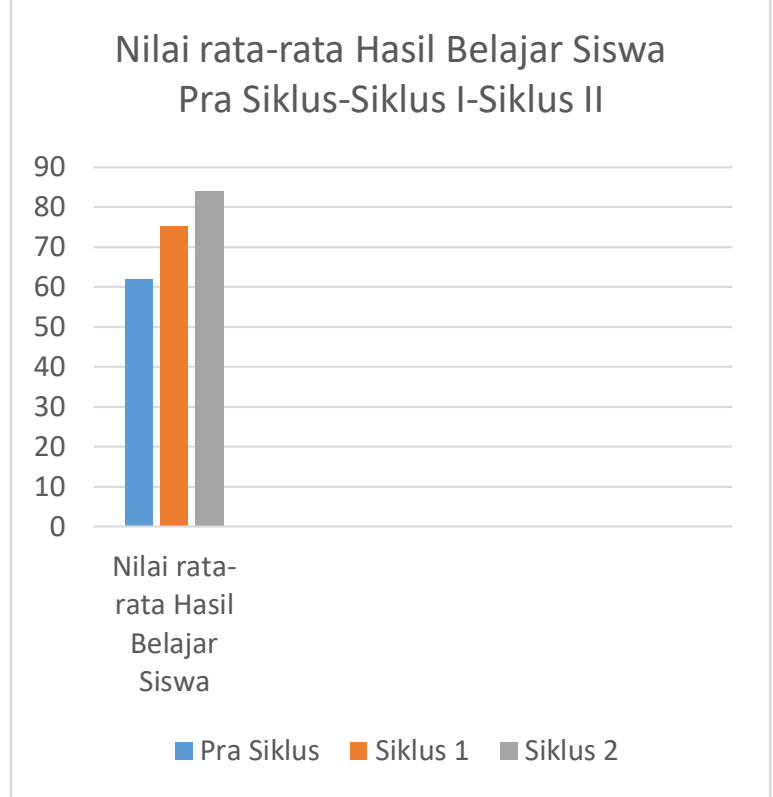

Berikut ini disajikan diagram data ketuntasan klasikal hasil belajar siswa dari pra siklus-siklus I-siklus II:

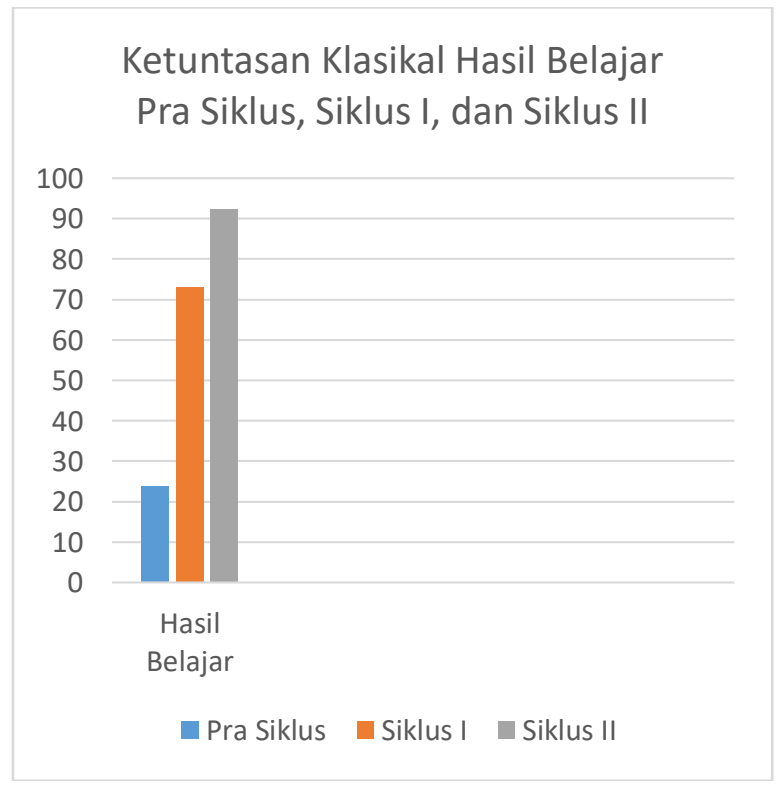

Diagram 1 Hasil Belajar Pra Siklus-Siklus ISiklus II 
Dari data peningkatan Hasil Belajar siswa tersebut dapat disimpulkan bahwa penerapan media peta tiga dimensi melalui pembelajaran tutor sebaya dapat meningkatkan hasil belajar siswa pada mata pelajaran IPS tema Indahnya Keragaman di Negeriku dengan subtema Indahnya Keragaman Budaya Negeriku.

Kegiatan observasi dilakukan selama proses belajar mengajar berlangsung untuk mengetahui keaktifan siswa selama pembelajaran. Pada kegiatan pra siklus dilakukan pembelajaran secara konvensional diperoleh data sebagai berikut:

Tabel 5. Rekapitulasi Hasil Observasi

Aktivitas Siswa pada Pra Siklus

\begin{tabular}{clcc}
\hline No & Aktivitas Siswa & $\begin{array}{c}\text { Jumlah } \\
\text { Prosen } \\
\text { tase }\end{array}$ \\
\hline 1 & $\begin{array}{l}\text { Mendengarkan } \\
\text { penjelasan guru }\end{array}$ & 14 & $54 \%$ \\
2 & $\begin{array}{l}\text { Melakukan } \\
\text { interaksi tanya } \\
\text { jawab dengan } \\
\text { guru }\end{array}$ & 10 & $39 \%$ \\
3 & $\begin{array}{l}\text { Siswa aktif } \\
\text { dalam diskusi } \\
\text { bersama } \\
\text { kelompok } \\
\text { Mengerjakan } \\
\text { tugas secara } \\
\text { individu } \\
\text { Menyelsaikan } \\
\text { tugas dengan } \\
\text { tepat waktu }\end{array}$ & 15 & $58 \%$ \\
\multicolumn{1}{c}{ Rata-rata } \\
5
\end{tabular}

Berdasarkan tabel 5 hasil observasi siswa menunjukkan perolehan aktivitas siswa mencapai $51 \%$. Hal ini berarti indikator keberhasilan belum mencapai $75 \%$, maka perlu dilakukan perbaikan pembelajaran.

Pada kegiatan siklus I dilakukan kegiatan pembelajaran dengan menggunakan media peta tiga dimensi diperoleh data sebagai berikut:

Tabel 6. Rekapitulasi Observasi Siswa pada Siklus I

\begin{tabular}{ccc}
\hline No & Aktivitas Siswa & \begin{tabular}{c} 
Jumlah $\begin{array}{c}\text { Prosen } \\
\text { tase }\end{array}$ \\
\hline
\end{tabular} \\
\hline
\end{tabular}

\begin{tabular}{llcc}
\hline 1 & $\begin{array}{l}\text { Mendengarkan } \\
\text { penjelasan guru } \\
2\end{array}$ & 20 & $77 \%$ \\
& $\begin{array}{l}\text { Melakukan } \\
\text { interaksi tanya } \\
\text { jawab dengan } \\
\text { guru }\end{array}$ & 18 & $69 \%$ \\
3 & $\begin{array}{l}\text { Siswa aktif } \\
\text { dalam diskusi } \\
\text { bersama } \\
\text { kelompok } \\
\text { Mengerjakan } \\
\text { tugas secara } \\
\text { individu } \\
\text { Menyelsaikan } \\
\text { tugas dengan } \\
\text { tepat waktu }\end{array}$ & 17 & $65 \%$ \\
\multicolumn{1}{c}{ Rata-rata } \\
\end{tabular}

Berdasarkan tabel 6 hasil observasi siswa menunjukkan perolehan aktivitas siswa mencapai $72 \%$. Jika dibandingkan dengan pra siklus mengalami kenaikan sebesar $12 \%$. Hal ini berarti indikator keberhasilan belum mencapai $75 \%$, maka perlu dilakukan perbaikan pembelajaran siklus II.

Pada kegiatan siklus II dilakukan pembelajaran dengan menggunakan media tiga dimensi dengan pembelajaran tutor sebaya diperoleh data sebagai berikut:

Tabel 7. Rekapitulasi Observasi Siswa pada Siklus II

\begin{tabular}{clcc}
\hline No & \multicolumn{1}{c}{$\begin{array}{c}\text { Aktivitas } \\
\text { Siswa }\end{array}$} & $\begin{array}{c}\text { Jumlah } \\
\text { siswa }\end{array}$ & $\begin{array}{c}\text { Prosent } \\
\text { ase }\end{array}$ \\
\hline 1 & $\begin{array}{l}\text { Mendengarka } \\
\text { n penjelasan } \\
\text { guru }\end{array}$ & 26 & $100 \%$ \\
2 & $\begin{array}{l}\text { Melakukan } \\
\text { interaksi } \\
\text { tanya jawab } \\
\text { dengan guru }\end{array}$ & 20 & $77 \%$ \\
3 & $\begin{array}{l}\text { Siswa aktif } \\
\text { dalam diskusi } \\
\text { bersama } \\
\text { kelompok } \\
\text { Mengerjakan } \\
\text { tugas secara } \\
\text { individu } \\
\text { Menyelsaika } \\
\text { n tugas } \\
\text { dengan tepat }\end{array}$ & 21 & $92 \%$ \\
\hline
\end{tabular}




\begin{tabular}{ll}
\hline waktu & \\
\hline Rata - rata & $87 \%$ \\
\hline
\end{tabular}

Berdasarkan tabel 7 hasil observasi siswa menunjukkan perolehan aktivitas siswa mencapai $87 \%$. Jika dibandingkan dengan siklus I mengalami kenaikan sebesar $15 \%$. Hal ini berarti indikator keberhasilan sudah mencapai lebih dari $75 \%$, maka perbaikan pembelajaran cukup sampai pada siklus II.

Berikut ini disajikan diagram data observasi siswa dari hasil penelitian yang diperoleh pada Pra siklus, siklus I, dan siklus II:

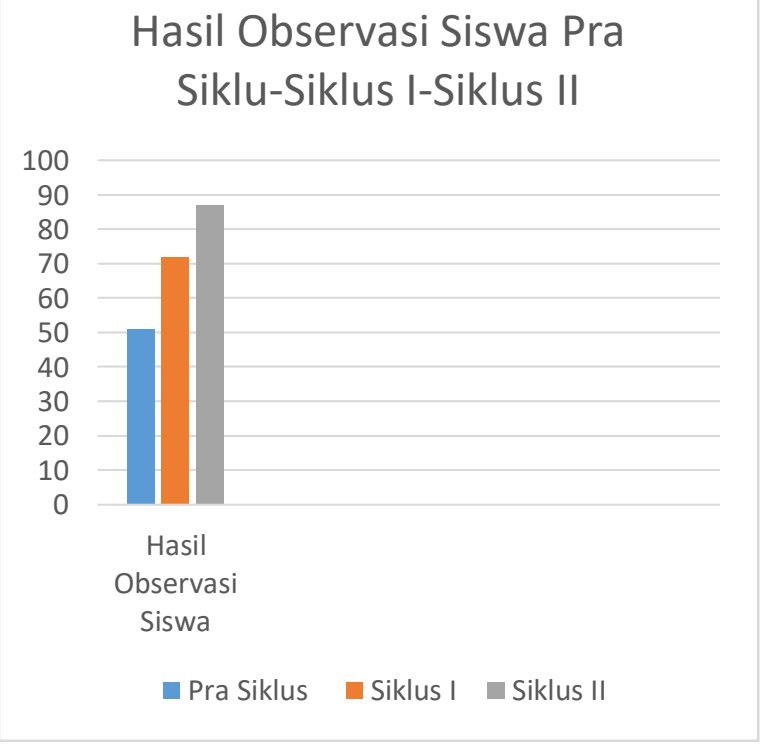

Dari data peningkatan aktivitas siswa tersebut dapat disimpulkan bahwa penerapan media peta tiga dimensi melalui pembelajaran tutor sebaya dapat meningkatkan aktivitas siswa pada mata pelajaran IPS tema Indahnya Keragaman di Negeriku dengan subtema Indahnya Keragaman Budaya Negeriku.

\section{KESIMPULAN}

Berdasarkan hasil penelitian dan analisis yang telah dilaksanakan selama dua siklus dapat disimpulkan bahwa penerapan media pembelajaran peta tiga dimensi melalui pembelajaran tutor sebaya dapat meningkatkan hasil belajar IPS pada siswa kelas IV SDN Banjaran Kecamatan Driyorejo Kabupaten Gresik. Hal ini dapat dilihat pada data rata-rata hasil belajar siswa yang mengalami peningkatan dari pra siklus $62,12 \mathrm{ke}$ hasil siklus I 75,19, dan hasi siklus II mencapai
84,14. Ketuntasan hasil belajar siswa secara klasikal juga mengalami peningkatan dari pra siklus $23,81 \%$ ke siklus I $62,12 \%$ ke siklus II sebesar $92,31 \%$.

Aktivitas belajar siswa juga mengalami peningkatan dari pra siklus sebesar $51 \%$ kemudian siklus I $72 \%$ dan siklus II mencapai $87 \%$. Dengan demikian penerapan media pembelajaran peta tiga dimensi dapat meningkatkan hasil belajar IPS dan keaktifan siswa kelas IV SDN Banjaran Kecamatan Driyorejo Kabupaten Gresik.

\section{SARAN}

Penerapan media pembelajaran peta tiga dimensi melalui pembelajaran tutor sebaya khususnya pada masa pandemi Covid19 membutuhkan persiapan dan koordinasi yang baik antara siswa, guru, dan wali murid agar tercipta pembelajaran yang efektif.

\section{UCAPAN TERIMA KASIH}

Ucapan terimakasih kami sampaikan kepada Ristekdikti yang telah mendanai penelitian ini, kepada LPPM dan seluruh pihak yang telah membantu penelitian ini.

\section{DAFTAR PUSTAKA}

Anitah W, Sri. Dkk. (2014). Strategi Pembelajaran di SD. Tangerang: Universitas Terbuka.

Arikunto, Suharsimi. (2010). Prosedur Penelitian: Suatu Pendekatan Praktik. Jakarta: Rineka Cipta.

Asyhar, (2011), Kreatif Mengembangkan Media Pembelajaran, Jakarta: Gaung Persada (GP) Press

Daldjoeni,N.(2014). Pengantar geografi. Yogyakarta : Ombak dua.

Dimyati dan Mujiono. (2013). Belajardan Mengajar. Jakarta: PT. Rineka Cipta.

Dina Indriana. 2011. Ragam Alat Bantu Media Pembelajaran. Yogyakarta: Diva Press Jogjakarta

Majid, A. (2013). Strategi Pembelajaran. Bandung: PT Remaja Rosdakarya.

Mastrianto, Agus dkk. (2017). Efektivitas Penggunaan Model Pembelajaran Tutor Sebaya Untuk Meningkatkan 
Minat Belajar Siswa. Jurnal Fkip Unila.ac.id

Mukhlis,Abdul.(Ed).2000. Penelitian Tindakan

Kelas.Makalah Panitia Pelatihan

Penulisan Karya Ilmiah untuk Guru-

Guru Se Kabupaten Tuban

Muzaki, Faiz dkk. 2014. Pengembangan Media Peta Timbul Kenampakan ALam IPS Bagi Siswa Tuna Netra Kelas VI SDLB. Journal Ortopedagogia Vol 1No 3hal 190.

Ningsih, W. K, dkk. (2019). The Development of Pop Up $3 D$ General Map Using Discovery Learning Models to Improve Creativity and Learning Outcomesof Social Studies Grade V Elementary School. International Journal For Educational and Vocational Studies. Vol 1. No 2: 86-91.

Nur,M.dan Wikandari,P.R.(2000). Pengajaran Berpusat Kepada Siswa dan Pendekatan Konstruktivistik dalam Pengajaran. Surabaya:Unesapress.

Oloo, Elizabeth A, dkk (2016). Effect Of Peer Teaching Among Students On Their Performance

Mathematics.International Journal of Scientific Research and Innovative Technology. Vol. 3 No. 12: 10-24.

Sanjaya, Wina. (2011). Strategi Pembelajaran Berorientasi Standar Proses Pendidikan. Jakarta: Kencana Prenada Media.

Setyawan, A. D. C, dkk (2017). Pengembangan Media Tiga Dimensi dalam Pembelajaran Model Student Team Achievement Division untuk Meningkatkan Hasil Belajar Siswa pada Subtema Lingkungan Tempat Tinggalku Kelas IV Sekolah Dasar. Jurnal Review Pendidikan Dasar: Jurnal Kajian Pendidikan dan Hasil Penelitian. Vol 3. No. 2: 398-404. 